\title{
Occurrence of Pseudomonas corrugata Causing Pith Necrosis on Tomato Plants in Goiás, Brazil
}

\author{
Alice M. Quezado-Duval ${ }^{1}$, Carielli M.N. Guimarães ${ }^{1}$ \& Olinda M. Martins $^{2}$ \\ ${ }^{1}$ Embrapa Hortaliças, Cx. Postal 218, CEP 70359-970, Brasília, DF, Brazil, e-mail: alice@cnph.embrapa.br; ${ }^{2}$ Embrapa \\ Recursos Genéticos e Biotecnologia, Cx. Postal 02372, CEP 70770-900, Brasília, DF, Brazil
}

Author for correspondence: Alice M. Quezado-Duval

\begin{abstract}
RESUMO
Ocorrência de Pseudomonas corrugata causando necrose-da-medula em plantas de tomate em Goiás, Brasil Identificou-se Pseudomonas corrugata associada a sintomas de necrose-da-medula em campo de produção de tomate para mesa localizado no município de Goianápolis, Goiás, em 2006. A bactéria foi identificada por meio de PCR, utilizandose os iniciadores específicos PC5/1 e PC5/2. Realizou-se ainda testes fisiológicos e de patogenicidade que corroboraram na identificação. No Brasil, P. corrugata havia sido relatada apenas em São Paulo e no Rio Grande do Sul.
\end{abstract}

Pith necrosis of tomato (Solanum lycopersicum L. = Lycopersicon esculentum Mill.), caused by Pseudomonas corrugata Roberts \& Scarlett, is a vascular disease that can affect tomato plants at any growth stage and in different crop systems, such as greenhouses and open fields. In Brazil, this tomato disease was first reported in the State of São Paulo (Rodrigues Neto et al., Summa Phytopathol. 15:20, 1989). In the following year, it was reported on tomato plants grown in greenhouses in Rio Grande do Sul (Martins et al., Fitopatol. Bras. 15:125, 1990). In July 2006, six to eight percent of tomato plants, cv. Dominador, grown under furrow surface irrigation system in a field in Goianápolis, Goiás, presented foliage chlorosis, with dark brown coalescent lesions on their stems. Profuse presence of adventitious roots was also observed. Longitudinal cuts revealed cavities let by the total pith destruction (Figure 1A) and pith dark discoloration. $P$. corrugata was isolated from symptomatic samples received at the Plant Pathology Laboratory of Embrapa Hortaliças, Brasília. The bacterium was identified with specific oligonucleotide primers PC5/1 and PC5/2, following previous described protocol (Catara et al., Eur. J. Pl. Pathol. 106:753, 2000). A specific band of 1,100-bp was amplified for both isolates obtained from the samples and for the type strain IBSBF 647 (provided by Julio Rodrigues Neto) used as control (Figure 1B). No amplification occurred when primers $\mathrm{PC} 1 / 1$ and $\mathrm{PC} 1 / 2$ specific for $P$. mediterranea (= P. corrugata phenon B) were used (Figure 1C). Bacterial colonies were yellowish with greenish center and wrinkled appearance. Diffused light green pigment was observed on nutrient agar with $5 \%$ of glucose. Fluorescence was not observed on King's B medium. The results of LOPAT (Lelliott et al., J. Appl. Bact. 29:470, 1966) tests were -, +, ,,-+- , showing that the bacterial isolates do not belong to $P$. syringae, $P$. viridiflava, $P$. cichorii or $P$. marginalis. Tomato plants cv. Yuba were inoculated by injecting a bacterial suspension $\left(\mathrm{A}_{600}=0.1\right)$ in the stem, at the point of the first true-leaf junction. Pith discoloration developed in the petiole after 20 days when the bacterium was recovered about $2 \mathrm{~cm}$ from the inoculation point.

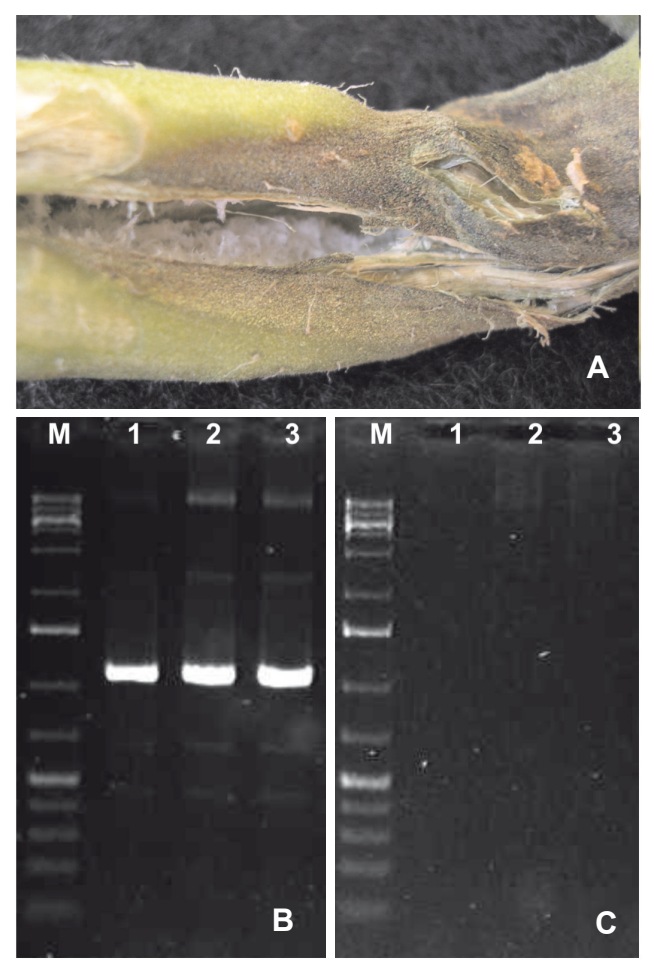

FIG. 1 - A. Symptoms of pith necrosis on tomato stem. B. PCR amplification with primers PC5/1 and PC $5 / 2$ of DNA from Pseudomonas corrugata, isolates IBSBF 647 (lane 1), CNPH 2006-1 (lane 2) and CNPH 2006-2 (lane 3). C. PCR with primers $\mathrm{PC} 1 / 1$ and $\mathrm{PC} 1 / 2$, specific to $P$. mediterranea. Lane M, $1 \mathrm{~kb}$ plus ladder.

Received 27 February 2007 - Accepted 6 December 2007 - FB 7019 